\title{
APPLICATION OF INTERNATIONAL LAW PRINCIPLES BY INTERNATIONAL TRIBUNALS Marian MIHĂILĂ
}

\author{
“Eftimie Murgu” University, Reşiţa, Romania \\ presedinte@uem.ro
}

\begin{abstract}
The observance of fundamental rules of public international law could be ensured only by the strengthening of penal law. However, despite several precedents assuring the good foundation of international law development in this respect and of the future endeavours expected to confirm the international society's adhesion to the penal repression requirements, the low convergence of public international law and criminal law reveals the difficulties that may occur in the way of a doctrine persuaded by the necessity to construct a new legal subject in the domain of peace. The legitimacy of constituting the International Tribunals was proved, but on the other hand they were reproached the very lack of legitimacy, being ad-hoc constituted jurisdictions instituted by the winners, made only by the representatives of the victor powers, which deprived them from a true international character and the fact that their legal foundation as regards the applicable law was shaky.
\end{abstract}

Keywords: principles, international penal courts, international tribunals, legitimacy, force, fundamental rights

\section{Introduction}

The remarkable ampleness of crime phenomena in contemporary society, the increasingly frequent harms to values interesting the international community on its entirety or focused on the interests of a large number of states, as well as the occurrence of organised crime exceeding the international borders by crime networks acting on the territory of several states, lie at the basis of the constitution and development of penal or criminal international law, as expression of efforts' coordination for the interdiction and repression of antisocial acts damaging to the legality and progress of the entire human society. International criminal law is necessary for peace and security preservation for the entire mankind and for the deployment, in accordance with the law and morality norms of the relations among states, for the existence and perenniality of mankind's fundamental values [1].

At their constitution, the relations among states were governed by public international law. Starting with the 20th century, when various divergences, clashes and wars among states took place, when a new economic-social system appeared, the relations among the states of the world got intensified to such an extent that the humanitarian law could no longer cover them. In this circumstance the idea appeared of a new international law branch, criminal international law. The foundation for the apparition of penal international law was constituted by the first large-scale conflagration among Europe's states - the First World War -, the growth of the criminal phenomenon harming international values embraced by many states, the occurrence of organised crime, commission of terrorist acts etc. 
2. The need for constituting the International Military Tribunals

Shortly after the Nuremberg verdict, the UN General Assembly adopted Resolution no. 95 meant to approve and confirm the principles of international law acknowledged by the Statute of the Nuremberg Court and its rulings. The resolution has a declarative character, confirming already existing principles and norms of international law, but establishing without equivoque their configuration and their general value, as part of the criminal international law.

Thus, the following were definitively recognised: principle of forbidding aggression war and of the liability of starting and fighting such a war; liability for war crimes and the struggle of the international community to sanction such crimes in the international plane or within the domestic penal system. Furthermore, the resolution affirmed the necessity to continually improve the international legislation and jurisdiction meant to make effective the punishment of any violation of international law in this field, and the need for codifying the existing principles and norms.

The results obtained in the settlement of important issues with direct incidence in the criminal international law, as well as the diligence still in progress for the development of such regulations, for the amplification effects in the sense of a wider cooperation in repressing crime, are the proofs that nowadays we are witnessing a wide affirmation of criminal international law, the shaping of its principles, instruments and methods meant to make it efficient in the fight to punish the violations brought to the law principles and norms and for the observance of international legality at peace and during armed conflicts.

The atrocity of the crimes committed during the Second World War determined the winning powers to take into consideration, even before the end of the war, the possibility of founding a tribunal empowered to judge the persons responsible for the crimes having marked the conscience of humanity. In this respect, the Moscow Declaration was signed on October 30th 1943, by which the Allied Powers intended to send the Nazi Party members and German military men liable for atrocities or crimes to the countries where the deeds were committed in order to be judged and punished according to the laws of the respective countries.

On that date, only the war crimes could fall within the competence of the Declaration. However, starting with 1944, data started to surface about the genocide [2] committed against the six million European Jews, arriving thus to the concept of "crimes against humanity". On the basis of the Moscow Declaration, on August 8th 1945 an agreement was signed in London, "The Agreement about the prosecution and punishment of major war criminals from European Powers and of the Axis". The governments of the United Kingdom of Great Britain and Northern Ireland, of the USSR and of the USA, as well as the provisional government of the French Republic, as signatory states of the Agreement, instituted an International Military Tribunal, with the headquarters in Nuremberg, destined to judge the war criminals whose deeds did not have an exact geographic location.

Whereas in Nuremberg Nazi criminals were still on trial, on January 19th 1946, based on the Potsdam Declaration, the Supreme Commander of the Allied Powers, General Douglas MacArthur, issued a decision to found the International Military Tribunal for the Far East, providing the legal frame for promptly punishing the major war criminals of the Far East.

It is interesting to remark that this tribunal was created by a simple proclamation of General MacArthur, and it functioned practically as an American court, which has had resonance even to our days [4].

From the perspective of the ratione personae jurisdiction, the International Military Tribunal for the Far East, unlike the Nuremberg International Military 
Tribunal, could judge only the persons accused of the commission of the most serious crimes, not being empowered to declare certain groups of organisations as having a criminal character.

Like the stipulations of the Statute of the Nuremberg International Tribunal, this court could rule the death penalty or any other verdict. As accessory to the ruling, the Court had the power to decide the seizure of any stolen property in the possession of the accused, sending them to the Supreme Commander of the Allied Forces.

After months of preparation, the International Military Tribunal for the Far East, also known as the Tokyo War Crimes Tribunal, reunited for the first time on April 29th 1946, and four days later the prosecutors presented the indictments, accusing the defendants of war crimes, crimes against peace and crimes against humanity. The trial lasted for more than two years and a half, 419 witnesses were heard, 4336 pieces of evidence were accepted, including statements from 779 people. The prosecution started the chapter Nanking of the indictment act in July 1946, and Doctor Robert Wilson, surgeon and member of the International Committee for the Safety Zone was the first witness.

It was the moment when most of the Japanese population found out for the first time about the unimaginable scope of the Nanking ,rape”. . „The horrid deeds of the Japanese army were now presented for the first time to the Japanese people" wrote the Asahi newspaper on the 26th of July.

One of the witnesses, Miner Searle Bates, a missionary and history teacher at the Nanking University, declared: „I have personally witnessed the shooting of several civilians, without provocation and without any reason."..., „The civilians' corpses lay in the streets and alleys around my house many days after the Japanese invasion". Bates declared before the court that Japanese soldiers used to randomly and systematically gather and execute Chinese POWs, they constantly raped women, incidents he saw with his own eyes in five distinct occasions, and he also witnessed how minutely they used to rob and plunder houses, shops and other buildings [3].

The international Military Tribunal for the Far East ruled the following:

- Death penalty for seven persons: Hideki Tojo and Koko Hirota, former Prime Ministers, and Generals Seishiro Hagaki, Kenji Doihara, Iwene Matui, Akira Muto, Heitato Keimura;

- Life in prison for eleven persons and different prison terms for other persons.

3. Criticism against the International Military Tribunal for the Far East

Even since its foundation, the Tribunal had to face much criticism. If we attempt to synthesise its content, we may refer to the following fact or circumstances:

$>$ All eleven judges came from victor states;

$>$ Except the Indian judge Pal Radhabinod, no other judge had had extended experience in international law;

$>$ The Chinese judge Mei Ju Ao had no experience as a judge in China or in other courts;

$>$ The USSR representative, General I.M.Zaryanov, spoke neither English nor Japanese, the two official languages of the trial;

$>$ The Philippine judge Delfin Jaranilla was a survivor of the Bataan death march;

$>$ The Australian judge and at the same time Chairman of the Court, William Webb, was involved in the investigations of the atrocities committed by the Japanese in New Guinea.

Emperor Hirohito and his family were granted immunity from the United States of America. Moreover, the USA - as revealed later on - decided not to bring before the court a series of members of the Japanese army, i.e. the officers and scientists of Unit 731, who conducted experiments with bacteriological weapons on human subjects in China, in exchange for the data obtained from the respective 
experiments.

The day the judgment was ruled, five out of the eleven judges presented separate opinions outside the tribunal. In his statement, Judge Webb referred to the legal status of Emperor Hirohito ...., „The fact that the emperor was constrained to act in this manner due to the counsel received is in contradiction with the evidence presented", wrote Webb. Although he abstained from accusing Hirohito, Webb underlined that he was liable, in his capacity of constitutional monarch who accepted ,ministerial advice and of other nature in the problem of war". Judge Jaranilla disagreed with the penalties established by the Court: „they are too lenient, in my opinion", he wrote, ,and are not exemplary and firm and in accordance with the seriousness of the crimes committed". Judge Henri Bernard from France highlighted the defective activity of the tribunal materialised in the absence of Emperor Hirohito and the insufficient deliberation of judges: ,a verdict reached by the court after a flawed procedure cannot be a valid verdict", concluded Bernard. Judge Bernard Roling from the Netherlands said that ,it was impossible to accurately and comprehensively define the concept of initiating and fighting an aggression war". The Indian judge Radhabinod Pal issued a 1235-page statement, in which he dismantled the legitimacy of the court, underlining its character of ,,justice of the winners". Taking into account the influence of the war propaganda, exaggerations and distortion of facts through the evidence, as well as zealous or hostile witnesses, Pal concluded however: ,the evidence that torture was inflicted by the members of the Japanese army against civilian populations in some occupied territories and prisoners of war is overwhelming".

Both the Nuremberg International Military Tribunal and the International Military Tribunal for the Far East was the target of extensive criticism, related especially to the "issue of impartiality" of the act of justice. In consideration thereof, under UN aegis efforts were made and preoccupations occurred, after the Second World War, to create an international court [5].

Theories about the criminal liability of states were formulated by Vespasian Pella more than two years before the international acts at the end of the Second World War by instituting in Nuremberg and Tokyo tribunals for judging the major war criminals. The Romanian jurist had, thus, the merit to anticipate a series of juridical theses and constructs that found their place only much later in the international thinking. We should however underline that this great idea about the creation of an International Criminal Court could not be concretised, as the Nuremberg court and the Tokyo court were, as we all know, exceptional tribunals judging only certain criminals, more precisely the major war criminals. The other criminals were judged, as it is known, by diverse national courts. In the legal science discussions continued, however, in the post-war years, related to the acceptance of the founding of an International Penal Court, many states manifesting reluctance to such an idea and appreciating that it is not desirable that their own citizens, even after having committed serious crimes, should be entrusted to international courts for trial, instead of being judged by their own tribunals. Nevertheless, the idea of the International Penal Court remains an extremely important idea, that even Vespasian Pella considered a guarantee for international peace and stability, for cooperation among states meant to contribute to the elimination of crimes that could harm the interests of a large number of states, in fact of the entire international community.

\section{Conclusions}

A frequently invoked law issue was that the defendants cannot be made criminally liable because they acted as representatives of the state, supporting the doctrine of the 
"state act", so that the German state was, in the conception of the defence, the only guilty party for the entire profusion of crimes and massacres deliberately committed by the Nazi armies.

The Court however rejected this theory, motivating among others that ,he who violated the laws of war cannot, in this respect, invoke the mandate he received from the state if the state, giving this mandate, exceeded its powers recognised by the international law."

If it had admitted the theory of the act of state, the Nuremberg International Military Tribunal would have had to pronounce the acquittal of all major war criminals prosecuted. It would also mean to assure the impunity of the perpetrators of international law crimes, compromising thus the idea of international justice.
Strengthening this idea, the rulings of the Nuremberg International Military Tribunal reads: ,the crimes against international law are committed by people, not abstract entities, and only by punishing the individuals who commit such crime the provisions of the international law can be applied".

The Nuremberg International Military Tribunal stands out as the first historic experience of instituting and operating the legal mechanism of international criminal justice enforcement, and has the merit to have consecrated in the international law the principle of individual criminal liability to the detriment of the penal liability of legal persons, settling at that moment the historic dispute in favour of the individual criminal liabiality and not of the legal person's penal liability.

\section{References}

[1] Vasile Creţu, Criminal international law (in Romanian), Tempus Society Editions, Bucharest, 1996, pp. 3-4.

[2] Stephen R. Shahom, “The Milosevic Indictment”, Znet, September, 20, 2001.

[3] Alexandru Bolintireanu, Adrian Năstase, Bogdan Aurescu, Contemporary international law (in Romanian), All Beck Publishing House, 2nd edition, Bucharest, 2000.

[4] Claudia Andriţoi, Analysis of the new paradigm of rights in the globalisation era, in Annals of DAAAM for 2009 \& Proceedings of 20th DAAAM International Symposium Publishing of research/scientific report as paper in ISI Proceedings, pp. 259-261, ISSN 1726-9679.

[5] Claudia Andriţoi, The alternative usage of law, study presented at "The 16th international scientific conference Knowledge-Based Organization", 25-27.11.2010, Land Forces Academy, Sibiu, ISSN 1843-6722, Proceeding ISI ranked. Web of Knowledge [v.5.11] - All Databases Results.htmprogr_KBO_2010.pdf. 